\title{
IMPACT OF AGRICULTURAL ADVISORY SERVICE ON DEVELOPMENT OF AGRICULTURAL PRODUCTION
}

\author{
Mlađan Dimitrijević ${ }^{1}$, Vladislava Stojić ${ }^{2}$ \\ *Corresponding author E-mail: kgdimasc@gmail.com
}

\begin{abstract}
A R T I C LE IN F O
A B S T R A C T

Review Article

Agricultural advisory includes coordination between

Received: 16 April 2019 people, modern technology and natural conditions. Since

Accepted: 13 June 2019 in the conditions of domination of small family farms, the agricultural advisory service along with agricultural doi:10.5937/ekoPolj1902617D

UDC 631.1:005.942]:338.432

Keywords:

agriculture, agricultural advisory, development factors cooperatives represents one of the two hubs of the agricultural development of Serbia, the aim of this paper is to determine, on the basis of analysis of the current development and present performance of the agricultural advisory service, the need to provide new forms of advisory services. The successful organization and practical functioning of the agricultural advisory service, JEL: Q012 especially in unstable economic conditions, is essential for achieving the development goals of Serbia's agriculture. There are already many activities of the advisory service, but the aim of this paper is to analyze the extent to which the agricultural advisory service in Kragujevac influenced the development of agricultural production in the surrounding villages. The obtained results indicate that the agricultural advisory service in Kragujevac has very little influence on the development of agricultural production in the surrounding villages.
\end{abstract}

(C) 2019 EA. All rights reserved.

\section{Introduction}

The agricultural advisory service is a necessary institution in the development of agriculture and villages, especially in the conditions of the post-socialist transition of the dual concept of development of our agriculture. Small family farms, dominant in production capacities, could not make a significant contribution to the overall development of our agriculture, especially in the realization of commodity agricultural production. Among the significant institutional factors whose insufficient presence has negatively affected the overall development of our agriculture, and especially

1 Mlađan Dimitrijević, Student Center Kragujevac, Radoja Domanovića 12, Kragujevac, Serbia, Phone: +38134336065, E-mail: office@studentskicentar-kg.rs

2 Vladislava Stojić, Assistant, Department of Medical Statistics and Informatics, Faculty of Medical Sciences, University of Kragujevac, Serbia, Phone: +38134306800 , E-mail: vladislavastojic@medf.kg.ac.rs, ORCID:http://orcid.org/0000-0002-9532-810X 
agricultural production in family farms, analysts of our agrarian practice necessarily include the engagement and assortment of agricultural advisory services.

The subject of the work is a comprehensive review and analysis of the agricultural advisory service, which has a special importance and role in the process of training agricultural workers for European integration, in particular for the implementation of the standards of agrarian policy, technology and technology of agricultural production and the concepts of rural development that are applied in the European Union. The European Union's trade strategy since 2006 has been justified on the assumption that deep and comprehensive bilateral trade agreements are at worst complementary to and at best promote multilateral negotiations, sustainability and democracy (Garcia et al., 2018; Smith and Stirling, 2018; Meilă, 2018).

Since in the conditions of domination of small family farms, the agricultural advisory service represents, with the agricultural cooperatives, one of the two hubs of the agricultural development of Serbia, the aim of the work is to draw on the analysis of the current development and present performance of the agricultural advisory service (tasks, organization, financing, material resources and staffing potential), points to the need to provide new forms of counseling services in rural areas.

The successful organization and practical functioning of the agricultural advisory service, especially in unstable economic conditions, is essential for achieving the development goals of Serbia's agriculture. There are already numerous advisory services, but the aim of the work is to point out the directions for adjusting agricultural advising to modern requirements of competitiveness of agriculture.

Based on the objectives and subject matter, the starting hypotheses are as follows:

1. The importance of agricultural production in the economy of the Republic of Serbia requires that the agricultural advisory service is well organized and efficient.

2. Education and professional development of farmers is necessary in modern business conditions, so that they can be informed and trained for modern production methods within their activities and be able to solve problems in organizing agricultural production.

3. Informal forms of education of farmers in Serbia are not sufficiently theoretically, neither methodologically defined nor standardized.

The first part of the paper includes the consideration of the importance of agricultural advisory in market-oriented agriculture. The need for entrepreneurship is that the choice in the field of technology is carried out with the help of agricultural advisory services. Within this part of the paper, the basic concepts of agricultural advising, the emergence and development of agricultural advisory services, the basic objectives of the functioning of the advisory service, with the basic concepts of advisory work as well as systems of knowledge and information in agriculture are explained. The second part is a survey aimed at determining the extent to which the agricultural advisory 
service in Kragujevac influences the development of agricultural production in the surrounding villages. The survey was conducted on a statistically representative sample, by random selection of household members in five villages around Kragujevac. Final considerations, in addition to the final analysis of theoretical considerations, include the evaluation of the results obtained by the research.

\section{Literature Review}

Agriculture is one of the promising and important industries for Serbia. The development of agriculture and the implementation of the process depend on many social and economic factors, from the achieved level of development of production forces and production relations and their influence on the state and attitude in the agrarian sector (Sekulić-Maksimović et al., 2018). For the agrarian development, creative power of knowledge and intellectual potential is vital - education as a process of acquiring knowledge, building skills, adopting a system of values, new technologies, business and organizational culture (Cukanović-Karavidić et al., 2018).

The term advisory is generally known and accepted by most people, but at the same time it does face rejection for various reasons: insufficient understanding of the meaning of the term itself, negative experience with advisors and advisory services, inadequate content of counseling, which in turn does not lead to sufficiently positive effects for organizers and donors etc.

In global terms, advisory is closely linked to the distribution of information to the population and the provision of assistance in assessing the large amount of information available to them for the purpose of finding a solution. Accordingly, advisory has the task of developing human resources. It places the person - the man at the center of its activities. Advisory is a process in which an advisor tries to motivate and encourage his client for a certain behavior through the provision of spiritual help so that he can solve his own problems in the right way. Clients then gain a better insight into the interconnectedness of the problem and identify possible alternative solutions. This way they become stimulated and focused on the behavior that leads to the overcoming of the problem. Thus, human resources are "liberated" and more fully exploited. It is important that the relationship between the advisor and the client is based on equality and that the advisor is committed to working for the benefit of the client. In addition, it is very important to preserve the decision-making autonomy and personal responsibility of the client, since he is obliged to bear responsibility for the consequences of his actions (Ogrizović and Teofanov, 2007). Finally, advisory can be viewed as a process through which an advisor tries to encourage and enable the client to overcome his acute problems.

The definition itself points to the fact that advisory is a very broad area and that advisors must have many skills and knowledge: in addition to a high level of knowledge regarding technical (professional) aspects in terms of what the client's interest is, they must also be familiar and skilled in the methodology of advisory work. However, the final decision on the extent of usefulnesss of the advisory content belongs to clients themselves. It is 
essential that the advisor has a positive attitude towards the client, which implies mutual respect, respect for the client as an equal partner and, of course, sincerity.

Advisory in agriculture should analyze the circumstances and needs of clients in advance, before precisely determining the objective of the advisory process. In almost all countries there is a history of joint activities in the local community and close family ties and connections among members of the local community. This justifies an advisory approach that is based on participatory advisory concepts and methods; the principles of self-help and the use of local available resources. Tumbas and Krmpotic (2001) highlight the following characteristics of the advisory approach:

1. The objectives must be clear, transparent and in line with the definition of the advisory service. The advisor may not have double roles. Advisory and monitoring are two independent processes that insist on different approaches.

2. The client is in the focus of an advisory approach. This implies that they are involved in the planning, monitoring and evaluation of advisory activities.

3. The adoption of the approach which emphasizes the process is a main task, with many smaller individual steps in the process which are accompanied by appropriate monitoring of data (certain indicators). Basically this means that an advisory organization has to work with the target group by focusing closely on their problems and finding alternative solutions to these problems together with them. Alternatives can be included in the advisory content.

4. The selection of adequate methods and instruments should be in harmony with the nature of the organization, the capabilities of the staff and the availability of local resources.

5. The homogeneity of the target group regarding their problems and situations, provides the potential for group advisory work.

6. During the work, policy and legal frameworks should be emphasized.

7. Without the technology to be offered, there is little chance that the advisory programs can have an impact on production.

The basic concept of this definition is "participation". Participation in advisory work involves joint decision-making and action by clients and advisors from agricultural advisory services (Čikić et al., 2008).

The Agricultural Advisory Service, which is one of the organizational and developmental instruments of agrarian policy, represents an important factor in the functioning and development of the economy, and it realizes its authority on development by achieving the set goals while respecting the specificities of the development policy. The main goal of the agricultural advisory is the harmonization of macro goals - the goals of the state with micro targets - the goals of the manufacturer. Harmonization of micro and macro goals at the level of agriculture is achieved through education and professional 
development of farmers. This stimulates the education and specialization of farmers for a given type of production, or for re-training, with the aim of finding possible opportunities for income (Mitrović et al., 2009). In today's business conditions, education and professional development of farmers are necessary for them to be informed and trained for modern production methods within their activities. This is of particular importance to our conditions, especially when it comes to the fact that the professional level of farmers is at a low level. Observed from this position, advisory should be a means by which additional knowledge and ideas are distributed in rural areas, and therefore lead to changes and improvements to the lives of farmers and their families. Proper organization and work of the agricultural advisory service are necessary in order to successfully accomplish this task (Hill, 2012).

Establishing an appropriate organization of the agricultural advisory service insists on providing adequate elements (personnel, financial, organizational, etc.) that ensure its proper work. It is particularly important that this organization is in line with the real needs of farmers as well as the changes taking place in their environment. In other words, counseling is a dynamic phenomenon that transforms and is forced to continually adapt to the resulting changes (Veselinović et al., 2002). Certainly, this is a continuous and very complex task, and therefore, it is very difficult to achieve. The modern advisory service in these areas is still not sufficiently developed. Of course, in the future, the existence of such a service will be necessary for successful implementation of the process of agricultural modernization.

Bearing in mind that there are many different advisory organization models, the problem of qualitative classification of these models is posed. In fact, the organization of these models ranges from a statewide organization of agricultural advisory, through semi-state models, to fully privatized consultancy. The type of model to be accepted depends on the level of agricultural development, the needs of the farmer for advisory services, and the developmental ability of the appropriate organization of agricultural advisory services. When it comes to Serbia, it is necessary, when selecting a counseling model, to provide all the necessary resources for its work, but also all the necessary information on how the functioning of already existing models works, as well as the possible problems and difficulties that these existing models face (Čikić et al., 2008).

Having a ready-made model of advice from a developed country does not necessarily mean that this model would be successful in our country. Accordingly, the appropriate model is one that is in line with the corresponding social and economic circumstances of the country in which it is applied.

The work of the advisory service falls under the jurisdiction of the state, regardless of whether it is in state, mixed or private ownership. Accordingly, the advisory service, as a state institution, should carry out its tasks through appropriate organizations such as the ministries of agriculture, regional agricultural stations, agricultural faculties and institutes, local agricultural services and various state or private development agencies. It is necessary that among these organizations there is an adequate distribution of jobs 
harmonized with the role and the importance that each organization carries in the process of distribution of knowledge, technology and innovation. In this case, the role of local economic development office and agricultural professional services created at local government level in Serbia is very important (Aničić et al., 2019).

The process of adopting farmers' decisions can be considered from different positions. Adoption of decisions represents a subjective and complex process, but it does not matter where the decision is made and who makes them. This claim applies to agriculture or farmers as decision makers (Janković, 2007). Certainly, auxiliary means are available, which are helpful to the farmer in raising the quality level of the decisions he makes. In order for the farmer to use them, it is necessary to develop appropriate skills for their implementation. The process of thinking starts from certain familiar information about an experiment or idea. Creating an idea, in general, is a deductive activity. Upon the creation of the idea, data is collected for its verification. That verification is empirical, in the form of testing certain claims. In doing so, using a rational flow of thinking raises the level of systematicity. Such a systematic course of reflection, which is used as a scientific method in practice, has also been shown on the farm in solving certain problems as the most effective means (Tumbas and Krmpotić, 2008).

The basic principles of doing business are an important tool in directing the deductive flow of thinking. They focus on the types of information that need to be collected and analyzed, and also provide an appropriate framework of information that can be used in the analysis of alternative decisions. In other words, they provide guidance for the decision-making process for farmers.

The process of selecting alternative decisions is a complex process that complicates the limitations of certain resources. For this purpose, the term alternative cost was introduced, which represents a loss of profit that could be realized using the same resources by choosing the next best alternative in decision making (Castle et al., 2002). This way, the economic principles directly emphasized the necessity of thinking about alternative decisions during the decision-making process. Implementation of the economic principles in decision making of farmers limits the lack of adequate information. It is not a rare case that the application of economic principles is criticized because it requires a larger amount of information than that available to the farmer. However, it is not possible to dispute the fact that economic principles provide a methodological basis for decision making.

The economic principles of the decision-making process are generally well-known, thus this paper will only outline them. Each production is based on an adequate relationship between the value of the input and the value of the output. As this relationship represents a rule, at the same time it represents a functional relationship or production formula (Tumbas and Krmpotić, 2008). This formula defines a change in yield depending on the transformation of the investment level of a particular production element that has an impact on the yield. The features of this formula are defined by the movement of total, average and marginal yields. The mutual relations of total yield, average yield 
and marginal yield in production represent the interdependence in which farmers make decisions about the amount and combination of investments of the available production elements. By appropriate analysis of these interdependencies, farmers can narrow down the range of possible alternatives to a rational measure. In addition, the limits of the rational height of the investment of the production factors are the maximum average yield and the maximum total yield.

Making a decision about the production of a certain product and the structure and level of production is determined by the costs. Costs are classified in several ways. It is important to determine their classification to fixed and variable costs, as the variable costs are crucial when deciding (Tomić and Živković, 2004). By inversing the relations of variables in the production formula, we get a cost formula - a new formula in the theory of production. Through the cost formula, it is observed how much the variable costs will be changed according to the quantity of products obtained.

The typology of advisory work enables the systematic, complete and precise registration, monitoring and analysis of the basic characteristics of the advisory work of each individual advisor. The type of advisory work identifies two main groups of characteristics:

1. General information about the user of the advisory services: name and surname of the user, place, farm code (if registered), date of obtaining advisory services

2. Information on advisory work: a group of advice to which the specific provided advice belongs (for each individual expert area of advisory work), the method of advisory work (individual or team), the method of giving advice (method of advisory work), the time required for giving advice, a brief description of a specific problem (Čikić et al., 2008).

Advisory work can be seen as a process of educating farmers with the aim to provide knowledge and information, as well as means for mastering certain skills, with the task of effectively solving problems that the farmer faces which can present a barrier to improving production and / or overall quality of life of the household or the local rural community of which the farm is an integral part. Like every educational process, advisory work implies certain aspects. Then you can talk about:

- the psychological aspect (it concerns the level of motivation of farmers for active participation in the advisory process, as well as their personal characteristics and preferences, but also the motivation of the advisor to actively contribute to the transfer of knowledge, innovations and technologies)

- pedagogical (didactic) aspect (it implies the available methods and tools for advisory work, as well as the ability of the advisor to apply them adequately to make the advisory process more efficient) and

- the sociological aspect (it includes a system of needs, values, norms and interests that determine the need and readiness of farmers to participate in this type of education, general 
social conditions in which counseling work takes place, as well as the characteristics of advisory organization and its basic goals) (Novković and Šomođi, 2009).

The effectiveness of the advisory work depends on the relationship between these three aspects. The theory of advising speaks of three basic methods of advisory work: individual, group method and advisory work using mass communication tools. These methods differ based on the method of implementation, the nature of the contact between the counselor and the farmer and the scope of the target group (Čikić et al., 2008). Regardless of the differences in the mentioned methods and their individual forms, their common goal is to ensure: establishing a trust relationship between an advisor and a farmer (target group members), distributing and acquiring knowledge and skills, increasing interest in advising farmers, and attracting and directing their attention to independently gaining the advantage of the practical application of new knowledge and skills.

The term individual metods of advisory work comprises advice given on the farm, at the station or by telephone. Group methods include lectures and other forms of group advisory work (demonstrations, field days, group discussions and workshops, excursions, trips, fairs, exhibitions, etc.). Advisory work through the use of mass media comprises advice provided through information technologies (e-mail, Internet), as well as the preparation and publication of printed material and education of farmers through means of mass communication (radio, television).

\section{Methodology of the Research}

The aim of the research is to analyze the extent to which agricultural advisory services in Kragujevac affect the development of agricultural production in the villages around Kragujevac. The agricultural station Kragujevac, as an expert service, covers the agricultural area of the Sumadija region with its work. This area has about 180,000 ha of arable land, with 120,000 ha of oranges, about 30,000 ha under fruits and vineyards, 30,000 ha of meadows, pastures, etc. Agricultural production is involved in more than 30,000 households in the area of 172 villages. In addition to expert staff, the Agricultural Station has the necessary laboratories and equipment: agrochemical laboratory, phytopathology and laboratory for quality control of seed of agricultural plants. There are three basic components of the content of the work: cooperation with scientists for practical application, education of the profession in all aspects of primary agricultural production and entrusted tasks by the Ministry of Agriculture (systematic control of fertility of the soil, control of production of seeds and planting material of agricultural plants, selection measures in livestock breeding, forecasting service).

The basic task of the agricultural advisory and expert service is the improvement of agricultural production, plant and animal husbandry on the farms of agricultural producers, the introduction of new varieties of hybrids of agricultural plants and domestic animal breeds, as well as the introduction of modern technology in the field of agriculture, in production. The financing of the service is done partially from the 
agrarian budget through the Ministry of Agriculture, Forestry and Water Management of the RS and partly from the market revenues by providing professional services to organizations in this area. Advisory services for agricultural producers are free of charge. Supervision of the work of the agricultural service is carried out by the Ministry of Agriculture and Forestry of the RS.

The survey was conducted on a statistically representative sample, by random selection of household members in five villages around Kragujevac (Lužnice, Cerovac, Desimirovac, Pajazitovo and Grbice). The units of observation are members of the households with agricultural production. The sample is stratified to cover parts of the pilot areas belonging to rural areas, according to international standards. The research is focused on members of agricultural households, regardless of the socio-economic structure (farm size, source of income, etc.). The survey was conducted in January 2019 by the author of the paper. A questionnaire for rural household members included a set of questions from the following areas:

- Selection questions

- Data on household members

- Household data

- Perception of potentials, attitudes, estimates, desires, plans

- Partnership and assessment of national / local support to rural areas

- The role of the agricultural advisory service.

The obtained results of the survey research were tabulated and graphically interpreted in such a way that for each answer the average level at all five villages was shown. The results of the survey are grouped according to the statistical definition of household types, the subjective assessment of the source of income, the importance of agricultural income and the perception of the future of the household.

\section{Results and Discussion}

The survey was conducted on a statistically representative sample (54), formed by random selection of household members in 5 villages around Kragujevac (Lužnice, Cerovac, Desimirovac, Pajazitovo and Grbice). The unit of observation was a household with agricultural production. The research is focused on agricultural households, regardless of the socio-economic structure (farm size, household members, source of income, etc.).

\section{Selection questions}

The answers to the selection questions included data on household members (number, age, and gender), demographic characteristics of the household owner - decision maker (sex, education), country processing and employment of household members.

Almost all surveyed households in selected villages (98\%) have more than one member, and most of them have at least one member between 20 and 40 years of age (84\%). 
There are almost no households in which more than one member is employed outside agriculture (only 4\%) and almost all household and decision holders are elderly men $(89 \%)$, over 50 years of age (average age is 51.1 ). Households in which women are decision-makers are almost nonexistent. One of the reasons for the unsatisfactory age and gender structure of decision-makers in households is, most likely, the sociological nature and consequence of patriarchal family relationships.

\section{Data on household members}

The educational structure of household members showed an extremely low participation of the highly educated population in the total number of household members. Only $5 \%$ of household members have graduated from University, $2 \%$ have college diploma (three years of higher education), 39\% have graduated from a four-year high school, $21 \%$ have graduated from a three-year high school, $27 \%$ only have elementary school and $6 \%$ are with an incomplete elementary school education. The reasons should be sought in the fact that the majority of households surveyed (45\%) are of mixed type, according to the subjective assessment of members, while $31 \%$ define their farm as agricultural. Mixed households have a better educational structure than the agricultural one, which is also established for the rural population of the whole Serbia. More than half of household members (63\%) do not have an extra job besides agriculture, and those who do, do not do it on a daily basis, but occasionally when they get a chance.

\section{Household data}

Most households surveyed have a registered farm (71\%) and use the land for agricultural purposes. The results show that $28 \%$ of the respondents do not have a registered farm, and the main reasons are the lack of confidence (74\%) and insufficient information (11\%). The average size of the agricultural parcel, which is used for various types of agricultural production, is: fields and gardens $-2.2 \mathrm{ha}$, orchards -0.74 ha, vineyards $-0.18 \mathrm{ha}$, meadows and pastures $-1.62 \mathrm{ha}$, indicating a significant problem of property fragmentation.

Figure 1. Households possessing certain types of livestock

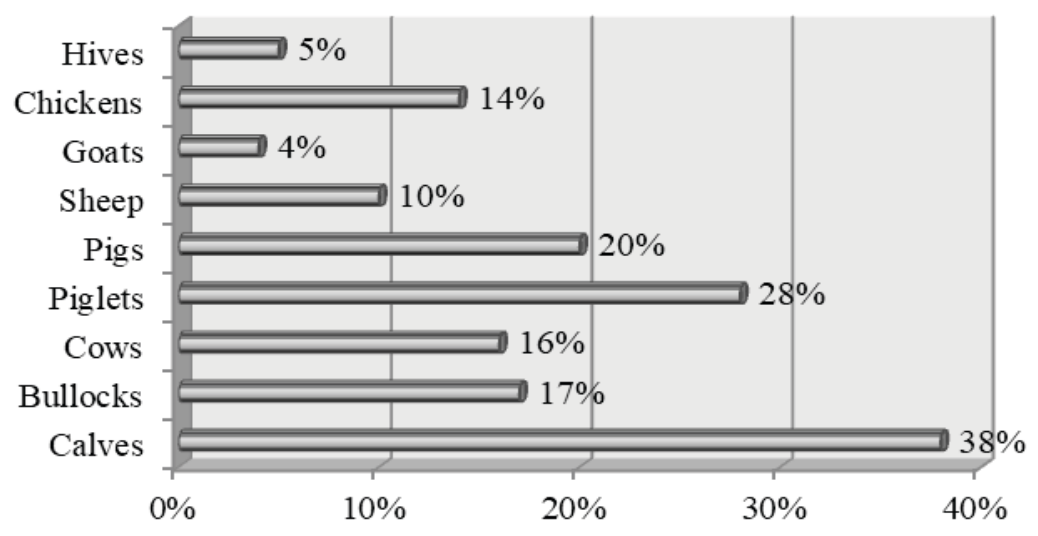

Source: Author's calculation 
The largest number of households surveyed produces corn and wheat, and a significant percentage $(67 \%)$ produces fruit production. The production of other cereals, vegetables, wood and other forest products are also significant factors in the structure of household income. In contrast to production, households mostly sell fruits and vegetables, and in a somewhat smaller percentage wood and other forest products. Households sell all agricultural products to local buyers and shopowners, at a rural green market and neighbors, while co-operatives have almost no redemption activities. Most respondents plan to maintain the same intensity and structure of agricultural production, and $27 \%$ even plan to increase production volumes.

However, it is indicative that $24 \%$ of the respondents did not give an answer to this question, which may indicate that they do not use long-term planning and assessment in their business, but they approach the decision-making promptly depending on the moment. Almost all surveyed households have a livestock fund (94\%), and the percentage of households that own certain cattle and sell livestock products is shown in Figure 1.

Figure 2. Percentage of surveyed households with mechanization

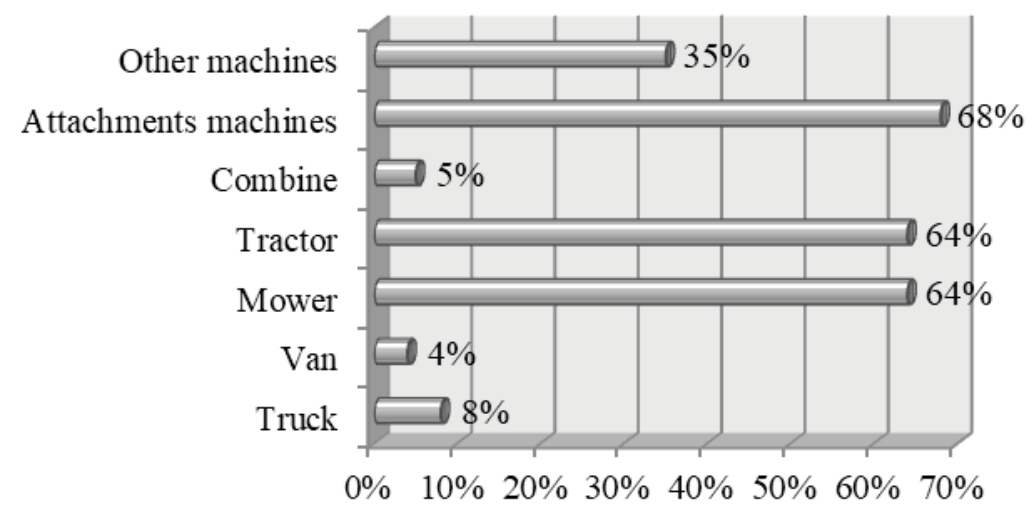

Source: Author's calculation

Households sell livestock products to marketers, in market towns and neighbors. Most respondents plan to keep livestock production at the same intensity, but a significant percentage $(25 \%)$ is planning to improve production.

However, there was again a relatively large percentage $(20 \%)$ of those who did not want to answer this question. Households, in general, own agricultural machinery. The largest number of households surveyed has a basic income from their own household (89\%).

\section{Perception of potentials, attitudes, estimates, desires, plans}

Almost half of surveyed households (46\%) view agriculture as an opportunity for future development. The employment of non-agricultural household members represents the possibility of progress for 34\% of households surveyed. Starting your own business $(15 \%)$ was seen as an additional opportunity for households to develop in the villages 
of the region. In this respect, $48 \%$ of respondents define the intensification of the use of their own land, and $34 \%$ of the stock fund as their plan for the future.

Figure 3. Possibility of household development

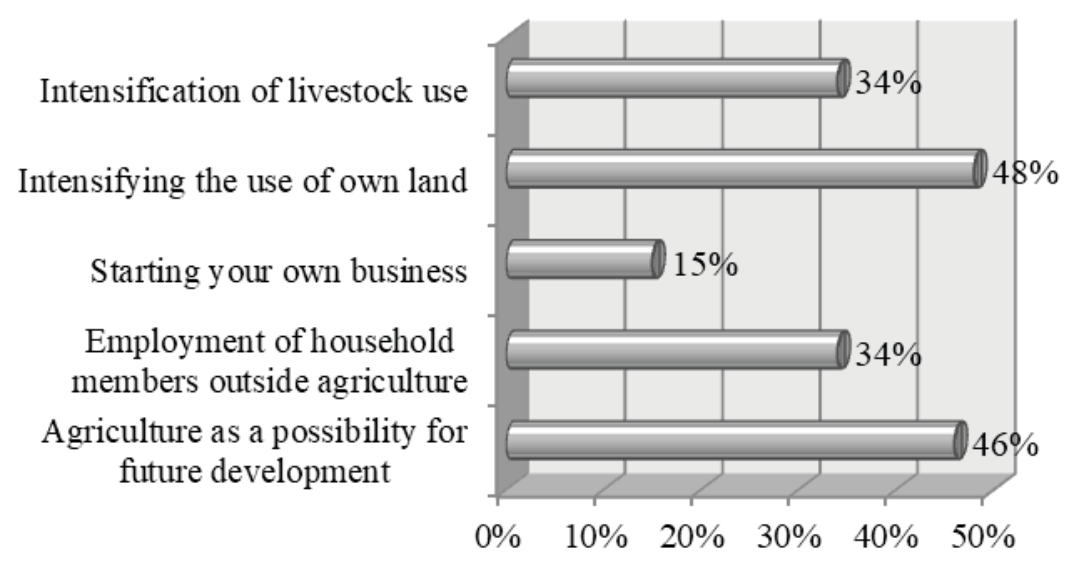

Source: Author's calculation

However, a significant number of respondents (as much as 50\%), in addition to expanding their agricultural capacities, intend to find work outside agriculture for themselves or members of the household. Only $16 \%$ of respondents see the chance for their household's future progress in starting their own business. $68 \%$ of households interviewed did not undertake any activity in order to start a new job in the last five years. Only 17\% of households started a new job and succeeded (craft, harvesting of forest fruits, trade), while $9 \%$ of the respondents tried, but failed to start a new job.

Figure 4. The most urgent support in the field of rural development

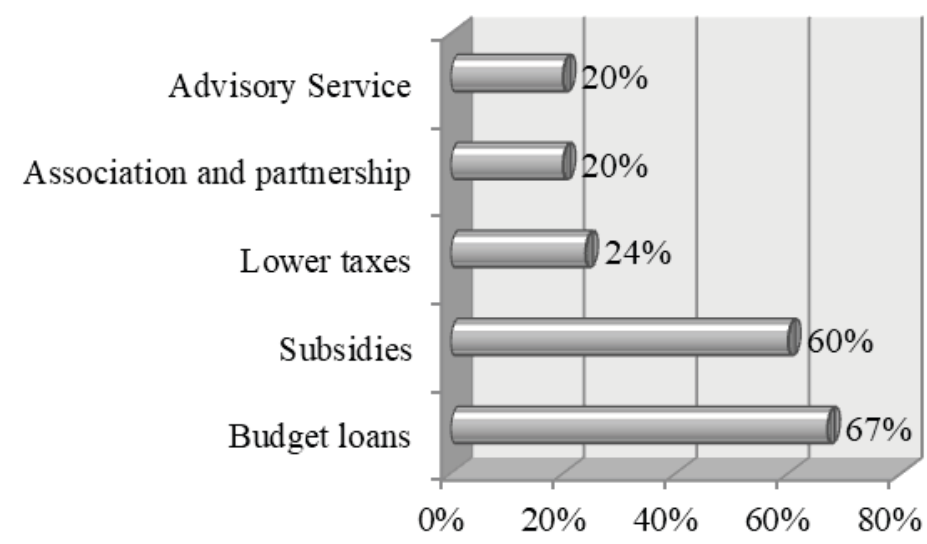

Source: Author's calculation

The lack of financial resources (31\%), inaccessibility of the market $(16 \%)$, lack of knowledge and experience (14\%), inability to find partners $(11 \%)$ were the main 
problems and constraints that householders faced in the attempt to start a new job, along with complicated paperwork (10\%) and high taxes and fees (10\%).

Figure 5. The most common reasons for professional help

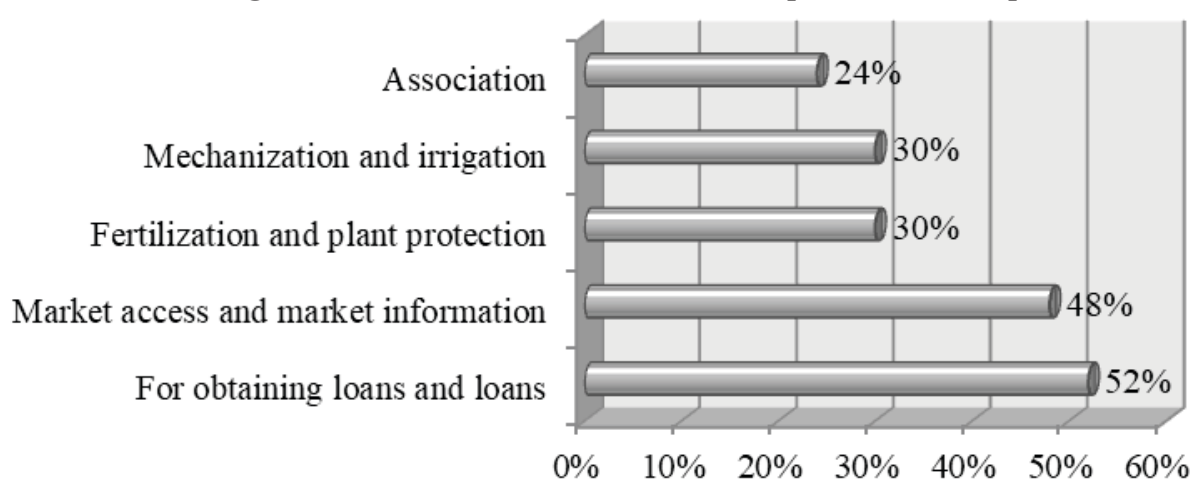

Source: Author's calculation

Favorable loans (67\%), subsidies (60\%), lower taxes (24\%), association and partnership $(20 \%)$ and counseling (20\%) represent the most favorable support in the field of rural development by the surveyed households. The most necessary professional assistance is about conditions and procedures for obtaining loans (52\%), access to market and market information (48\%), fertilization and plant protection $(30 \%)$, mechanization and irrigation (30\%) and association (24\%).

\section{Partnership and assessment of national / local support to rural areas}

Farmers have recognized themselves as the subjects that currently make the most of the quality of life for rural households (63\% of responses). In second place is the state-government and local self-government (58\%), followed by farmers' associations $(24 \%)$. Some households recognize counseling services (17\%), local entrepreneurs $(7 \%)$ as relevant factors with their own position.

Most households believe that the producers in their village are not united (81\%) in any way. On the other hand, most respondents occasionally (45\%) or regularly (39\%) work with neighbors or family members through an exchange of work, while only $6 \%$ never do it.

In the case of agricultural machinery and equipment, the largest percentage of respondents settles their needs with exchanges with neighbors and relatives (49\%), while $20 \%$ own their own machinery. Some hosts $(7 \%)$ are willing to pay for the use of machinery through renting a machine or engaging a machine with a worker who will do the work on their farm $(9 \%)$. 
Figure 6. Entities that contribute most to improving the quality of life of the household

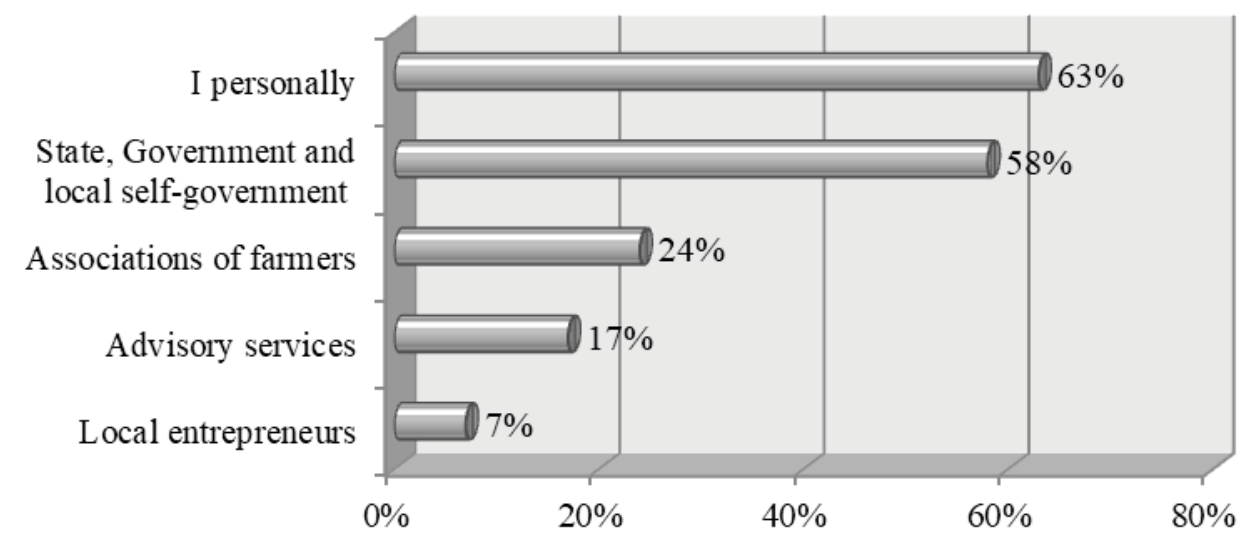

Source: Author's calculation

\section{The role of the agricultural advisory service}

A significant percentage of respondents (30\%) communicate with the advisory service only when their representatives visit them, but at the same time, a significant percentage (about $40 \%$ ) is ready to pay advisor services.

Figure 7. Use of state support funds

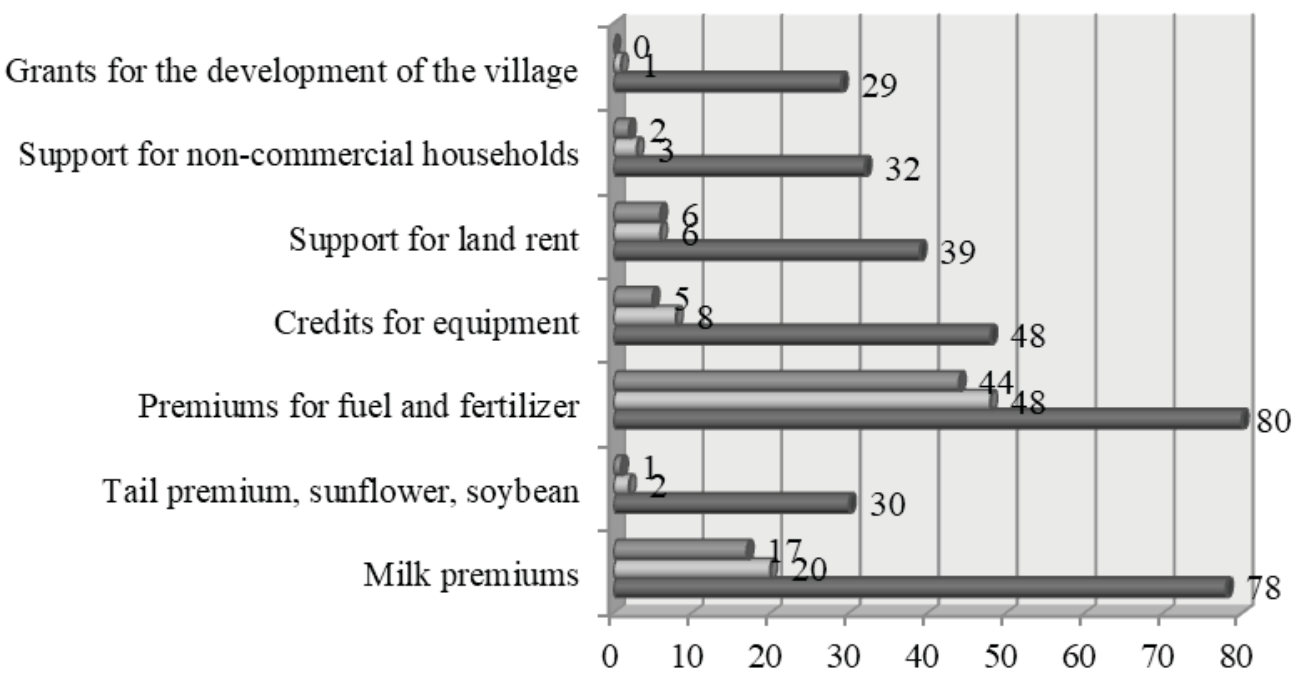

$\square$ Get it (\%) $\quad \square$ Applied (\%) $\quad$ They heard (\%)

Source: Author's calculation

At the national level, half of the interviewed households receive information in an informal manner (through talking to neighbors and relatives) or do not try to get 
information at all, while respondents show some more advanced habits - 73\% are informed via radio and television, $56 \%$ reported only over neighbors, $28 \%$ are consulted in a local agricultural pharmacy, and $15 \%$ read specialized magazines and consult a local agronomist or veterinarian and advisory service. Only 5\% reads the Bulletin of the Ministry of Agriculture, Forestry and Water Management of the Republic of Serbia. There are no households that do not even try to get information.

The surveyed agricultural households believe that they are familiar with the state support programs ( $42 \%$ ), but $15 \%$ of the respondents estimate that they do not know absolutely anything about them and that they are not interested in finding out. The largest percentage of respondents is informed about these programs via TV and radio, then through magazines, but also informally through conversation with neighbors and friends. A small percentage of surveyed households applied for some state support programs, and even fewer were supported.

The highest percentage of households applied for fuel and fertilizer refineries and milk premiums, and the regres are the most frequently obtained category.

\section{Discussion}

The obtained results of the survey on the extent to which the agricultural advisory service in Kragujevac influences the development of agricultural production in the villages around Kragujevac show that most of the surveyed households with a registered farm ( $71 \%$ ) use the land for agricultural purposes and process it, while $28 \%$ of respondents do not have a registered farm, and as main reasons they mention the lack of trust (74\%) and insufficient information (11\%). The results show that almost half of the surveyed households (46\%) view agriculture as a potential for future development.

A significant percentage of respondents (30\%) communicate with the advisory service only when their representatives visit them, but at the same time, a significant percentage (about $40 \%$ ) is ready to pay for advisory services. At the national level, half of the interviewed households receive information in an informal manner (through talking to neighbors and relatives) or do not try to get information at all, while respondents show some more advanced habits $-73 \%$ are informed via radio and television, $56 \%$ reported only over neighbors, $28 \%$ are consulted in a local agricultural pharmacy, and $15 \%$ read specialized magazines and consult a local agronomist or veterinarian and advisory service.

The surveyed agricultural households believe that they are familiar with the state support programs (42\%), but $15 \%$ of the respondents estimate that they do not know absolutely anything about them and that they are not interested in finding out. The largest percentage of respondents is informed about these programs via TV and radio, then through magazines, but also informally through conversation with neighbors and friends. A small percentage of surveyed households applied for some state support programs, and even fewer were supported. Based on the obtained research results, we can conclude that the agricultural advisory service in Kragujevac has very little influence on the development of agricultural production in the villages around Kragujevac. 


\section{Conclusion}

The advisory system develops communication links and realizes the exchange of information both within the system, between the elements of the structure and outside the system at the country level (banks, insurance companies, agricultural suppliers, processors of agricultural products, trade, carriers) and the international level. For the needs of the formation and equipping, development and efficient work of the advisory service and the system as a whole, stable sources of funding are needed. This primarily refers to the resources of the agricultural budget, which should form the basis for financing this system. The development of an advisory system conditioned by the diversity of individual agricultural areas must be selective, absolutely appropriate to the needs of areas that currently have development potential, and only partly to the needs of those areas that represent development potential in the near or distant future. Other areas of low development potential are not included in the development of advisory services, but are assisted by other forms of agricultural development.

The advisory system must be gradually built and must go a long way from the system in which all the activities of the organizations are financed by the budget funds and all services are free, through the system of partial participation of the users of services by charging certain services while other services are free, to the system in which all costs are covered by the service charge to the user and the system is able to finance itself. International experiences are first and foremost confirmed by the fact that the advisory system cannot be organized on the basis of templates, simply by utilizing one of the existing models. Each country has to build its own model of organizing advisory services that will respect the specifics of the country, and the experiences of others can be used as certain guidelines.

It is quite clear through the analysis of international experiences that while defining the development strategy of our country's advisory service, the alternative is the organization of an advisory network by the farmers' association. This is the best choice, the best solution that would not require further modifications later. However, the answer to the question of whether such a strategy can be implemented in our country is no. There are numerous reasons for such an answer, and the most crucial is that in our country there are no strong associations of farmers that represent their interests and that can fund an independent advisory organization from the collected funds for membership fees. However, some compromise must be found, even though it might not the best choice. The optimum alternatives that would be realized in the future should not be abandoned, but it is necessary to approach the organization of the state advisory system on new and changed concepts of development and to support the development of advisory services organized by production and trade organizations and individuals in parallel.

\section{Conflict of interests}

The authors declare no conflict of interest. 


\section{References}

1. Aničić, D., Nestorović, O., Simić, N., \& Miletić, S. (2019). The perspectives of sustainable development of Serbia's agriculture in globalized environment. Economics of Agriculture, vol. 66, no 1, pp. 221-235.

2. Castle, E., Becker, M. and Nelson, G. (2002). Farm Business Management. Macmillan Publishing Company, London.

3. Cukanović-Karavidić, M., Karavidić, S., Pejanović, R. (2018). Agro-economic development based on the economy of knowledge, business and social skills. Economics of Agriculture, vol. 65, no 3, pp. 1241-1257.

4. Čikić, J., Janković, D. i Petrović, Ž. (2008). Typology of advisory work. in: Ž. Petrović (ed.), Information system in the agricultural advisory service of Vojvodina. Faculty of Agriculture, Novi Sad, 38-56. [In Serbian: Tipologija savetodavnog rada. $\mathrm{u}$ : Sistem informacija u poljoprivrednom savetodavstvu Vojvodine]

5. Čikić, J., Petrović, Ž. i Janković, D. (2008). The role of the agricultural advisory service in encouraging the production of health-safe food. Thematic proceedings from the International Scientific Meeting: "Multifunctional Agriculture and Rural Development III - rural development and (un)limited resources", Faculty of Agriculture in Zemun, book II, 102-108. [In Serbian: Uloga poljoprivredne savetodavne službe u podsticanju proizvodnje zdravstveno bezbedne hrane]

6. Garcia-Duran, P., \& Eliasson, L. J. (2018). Squaring the circle: assessing whether the European union's pursuit of bilateral trade agreements is compatible with promoting multilateralism. Journal of Self-Governance \& Management Economics, 6(1), 7-32.

7. Hill, B. (2012). Farm Incomes, Wealth and Agricultural Policy: Filling the CAP's Core Information Gap. Wallingford, Oxfordshire, UK, Cambridge, MA.

8. Janković, D. (2007). Defining agricultural advisory. in: Cvijanović, D., V. Hamović, J. Subić (eds.) Multifunctional agriculture and rural development - preservation of rural values. The thematic collection from an international scientific meeting. Institute of Agricultural Economics, Belgrade, Faculty of Agriculture, Novi Sad, Faculty of Economics, Subotica, 938-945. [In Serbian: Definisanje poljoprivrednog savetodavstva. u: Multifunkcionalna poljoprivreda i ruralni razvoj - očuvanje ruralnih vrednosti]

9. Meilă, A. D. (2018). The Social Structure of Cities: The Multidimensional Nature of Urban Inequality. Psychosociological Issues in Human Resource Management, 6(1), 115-120.

10. Sekulić-Maksimović, N., Živadinović, J.\& Dimitrijević, L. (2018). Concerns about hamonization process of Serbian agricultural policy with EU standards. Economics of Agriculture, vol. 65, no. 4, pp. 1627-1639.

11. Smith, A., \& Stirling, A. (2018). Innovation, sustainability and democracy: an analysis of grassroots contributions. Journal of Self-Governance and Management Economics, 6(1), 64-97.

12. Novković, N. i Šomođi, Š. (1999). Agromenagement, Information Center, Padinska Skela, Belgrade. [In Serbian: Agromenadžent] 
13. Ogrizović, B. i Teofanov, S. (2007). The role and importance of the agricultural advisory service of AP Vojvodina. Modern agricultural technology, 33(3-4), 213 219. [In Serbian: Uloga i značaj poljoprivredne savetodavne službe AP Vojvodine]

14. Tomić, R., i Živković, D. (2004), Changes in the Agricultural Advisory Service of Serbia. Biotechnology, Vol. 20, 5-6, 293-300. [In Serbian: Promene u poljoprivrednom savetodavstvu Srbije]

15. Tumbas, P. i Krmpotić, T. (2001). Information in the decision-making process of farmers. Journal of Scientific Society of Power Machines, Tractors and Maintenance, 6 (2), 7-12. [In Serbian: Informacije u procesu odlučivanja poljoprivrednika]

16. Tumbas, P. i Krmpotić, T. (2008). Agricultural advisory-strategies and organizational models. Journal of Scientific Society of Power Machines, Tractors and Maintenance, 3 (5), 51-56. [In Serbian: Poljoprivredno savetodavstvo-strategije i modeli organizovanja]

17. Veselinović, B., Ševarlić, M. i Vasiljević, Z. (2002), Agricultural advisory service and education of manufacturers - the factor of integration into the European Union. Economist, (3), 189-200. [In Serbian: Poljoprivredna savetodavna služba i edukacija proizvođača - činilac integracije u Evropsku Uniju] 